\title{
ANALISIS FAKTOR-FAKTOR YANG MEMPENGARUHI KREDIT BERMASALAH PADA LPD DESA PAKRAMAN SIDETAPA KECAMATAN BANJAR, KABUPATEN BULELENG
}

\author{
Ni Luh Mira Yanti ${ }^{1}$, lyus Akhmad Haris², I Nyoman Sujana ${ }^{3}$, \\ Program Studi Pendidikan Ekonomi, Fakultas Ekonomi \\ Universitas Pendidikan Ganesha \\ Singaraja, Indonesia
}

e-mail: $\frac{\text { niluhmirayanti16@gmail.com } 1}{\text { suianatbn@yahoo.com }}$, $\frac{\text { iyusharis55@gmail.com² }}{2}$

\begin{abstract}
Abstrak
Penelitian ini bertujuan untuk mengetahui faktor-faktor yang mempengaruhi kredit bermasalah dan faktor yang dominan mempengaruhi kredit bermaslaah pada LPD. Jenis penelitian ini adalah penelitian faktorial. Populasi dalam penelitian ini adalah 137 orang debitur kredit bermasalah pada LPD Desa Pakraman Sidetapa. Metode pengambilan sampel yang digunakan adalah metode nonprobability sampling yaitu dengan sampling purposive, sehingga diperoleh sampel 60 responden. Data penelitian dikumpulkan dengan menggunakan kuesioner yang kemudian diolah dengan analisis faktor melalui bantuan SPSS 16.0 for Windows. Hasil penelitian menunjukkan bahwa faktor yang mempengaruhi kredit bermasalah pada LPD Desa Pakraman Sidetapa yaitu, berhubungan dengan kepentingan pribadi sebesar 4,965\%, kompromi terhadap prinsip-prinsip perkreditan sebesar 47,199\%, kebijakan perkreditn yang kurang sehat sebesar $2,126 \%$, tidak lengkapnya informasi kredit sebesar 8,863\%, kurangnya petugas menguasai teknik perkreditan sebesar 9,546\%, pemberian kredit yang melampaui batas sebesar 5,737\%, pengelolaan kredit sebesar $8,003 \%$, dan kondisi usaha sebesar $13,563 \%$. Faktor yang paling dominan mempengaruhi kredit bermasalah adalah faktor kebijakan perkreditan yang kurang sehat sebesar $47,199 \%$.
\end{abstract}

Kata kunci: Kredit Bermasalah, Lembaga Perkreditan Desa, Desa Sidetapa

\begin{abstract}
This study aims to determine the factors that influence non-performing loans and the dominant factors influencing non-performing loans based on the LPD. This type of research is factorial research. The population in this study were 1015 debtors in the LPD of Pakraman Sidetapa Village. The sampling method used is probability sampling method that is by simple random sampling, so that a sample of 91 respondents was obtained. Research data was collected using a questionnaire which was then processed by factor analysis through the help of SPSS 16.0 for Windows. The results showed that factors affecting non-performing loans in the Pakraman Sidetapa Village LPD were, self dealing of 3.392\%, compromise on credit principles of $7.472 \%$, unhealthy credit policies of $45.972 \%$, incomplete credit information amounting to $8.789 \%$, lack of officers mastering credit techniques by $9.35 \%$, credit extending beyond the limit of $5.007 \%$, credit management at $13.160 \%$, and business conditions at $6.896 \%$. The most dominant factor affecting nonperforming loans is an unhealthy credit policy factor of $45,972 \%$.
\end{abstract}

Keyword: Problem Loans, Village Credit Institution, Sidetapa Vilage 


\section{PENDAHULUAN}

Lembaga keuangan adalah suatu badan usaha yang mengumpulkan suatu aset dari masyarakat dalam bentuk dana dan disalurkan untuk pendanaan suatu proyek pembangunan serta untuk kegiatan ekonomi dengan mendapatkan hasil dalam bentuk bunga sebesar presentase tertentu dari besarnya dana yang disalurkan. Salah satu lembaga keuangan bank adalah Bank Perkreditan Rakyat (BPR), bank yang memberikan jasa keuangan dalam bentuk tabungan, simpanan yang berbentuk deposito berjangka, dan lainnya yang bentuknya sama, lalu menyalurkan dana tersebut untuk keperluan modal usaha masyarakat. Status BPR diberikan kepada Bank Desa, Lumbung Desa, Bank Pasar, Bank Pegawai, Lembaga Perkreditan Desa (LPD), Badan Kredit Desa (BKD), dan lembaga lainnya sesuai dengan UU Perbankan Nomor 7 Tahun 1992.

Lembaga Perkreditan Desa (LPD) merupakan badan usaha milik desa adat/pakraman yang bergerak dibidang perkreditan dan tidak semata-mata bergerak diranah ekonomi/sosial ekonomi, akan tetapi ada misi yang sangat penting yaitu menjaga kehidupan berbudaya. Dalam Perda Provinsi Bali Nomor 3 Tahun 2017 pasal 1 ayat 9 menyebutkan bahwa Lembaga Perkreditan Desa yang selanjutnya disebut LPD adalah lembaga keuangan milik desa pakraman yang berkedudukan di wewidangan desa pakraman.

LPD memiliki bidang usaha yang tercantum dalam Perda Provinsi Bali Nomor 3 Tahun 2017 pasal 7 ayat 1 yaitu yang pertama menerima atau menghimpun dana dari Krama Desa dalam bentuk dana sepalan dan dana sesepelan. Kedua, memberikan pinjaman kepada Krama Desa dan Desa. Ketiga, LPD dapat memberikan pinjaman kepada Krama Desa lain dengan syarat ada kerjasama antar desa. Keempat, kerjasama antar Desa diatur lebih lanjut dengan Peraturan Gubernur. Kelima, menerima pinjaman dari lembaga-lembaga keuangan maksimun sebesar 100\% (seratus persen) dari jumlah modal, termasuk cadangan dan laba ditahan, kecuali batasan lain dalam jumlah pinjaman atau bantuan dana. Keenam, menyimpan kelebihan likuiditasnya pada Bank yang ditunjukkan dengan imbalan bunga bersaing dan pelayanan yang memadai.

$$
\text { Lembaga keuangan pada }
$$

khususnya Lembaga Perkreditan Desa (LPD) Desa Pakraman Sidetapa memiliki kegiatan utama sebagai penyedia jasa yaitu menyalurkan dana dan menghimpun dana. LPD menghimpun dana dari masyarakat melalui simpanan dan kemudian menyalurkan dana kepada masyarakat umum dalam bentuk kredit atau pinjaman. Berbagai jenis kredit yang ditawarkan oleh pihak bank kepada para nasabah, diantaranya adalah kredit konsumtif dan kredit produktif. Kredit produktif adalah kredit yang digunakan dalam pengembangan usaha milik nasabah. Sehingga dengan adanya kredit produktif ini nasabah mendapat tambahan dana untuk usahanya. Sedangkan kredit konsumtif adalah salah satu jasa yang diberikan bank dalam bentuk kredit yang ditunjukkan untuk membiayai kebutuhan nasabah yang berhubungan dengan kebutuhan konsumsi.

$$
\text { Dalam menjalankan bidang }
$$

usahanya LPD menyalurkan dana kepada masyarakat dalam bentuk kredit. Kredit merupakan penyediaan sejumlah uang bank atau bentuk lain yang dapat dipersamakan dengan itu berdasarkan persetujuan pinjam meminjam antara bank dengan pihak debitur dan mewajibkan pihak debitur untuk melunasi hutangnya setelah jangka waktu tertentu dengan jumlah bunga yang disepakati (Sudirman, 2000).

Setiap pengajuan kredit kepada pihak bank atau lembaga keuangan lainnya harus melalui proses analisis kredit terlebih dahulu, baru kemudian ditentukan keputusan persetujuan kreditnya disetujui atau ditolak. Proses analisis kredit mempunyai tujuan utama yang paing hakiki, yaitu: agar bank membuat satu keputusan kredit yang baik dan benar "make a good loan", sehingga terhindar dari keputusan kredit yang keliru yang menyebabkan kredit bermasalah "bad loan" (Supriyono, 2011).

Pemberian kredit kepada debitur harus dilakukan dengan memperhatikan tujuan dan sifat kebutuhan dana (Herli, 2013). Menurut Lapoliwa dan Kuswandi (2000) jenis kredit yang diberikan oleh 
suatu bank akan bergantung pada produk kredit yang ditawarkannya. Kebutuhan dana beragam menyebabkan jenis kredit juga menjadi beragam. Hal ini disesuaikan dengan kebutuhan dana yang diinginkan nasabah.

Mengingat kredit adalah berbasis kepercayaan, maka pihak bank diharuskan menguji nasabahnya terlebih dahulu apakah nasabah dapat dipercaya, dalam arti uang yang dipinjamkannya dapat dikembalikan dalam jangka waktu yang telah disepakati bersama di awal kredit. Untuk itu sebelum kredit dicairkan, bank akan melakukan serangkaian proses kredit yang di dalamnya terdapat analisis kelayakan tentang kredit yang diajukan nasabah (Wahjono, 2010).

Kredit dalam arti luas diartikan sebagai sebuah kepercayaan (Abdulah dan Tantri, 2012). Maksud dari percaya di sini adalah ia percaya kepada si penerima kredit bahwa kredit yang disalurkannya pasti akan dikembalikan sesuai perjnajian. Sedangkan bagi si penerima kredit merupakan penerimaan kepercayaan sehingga mempunyai kewajiban untuk membayar sesuai jangka waktu. Dalam pemberian kredit oleh suatu bank akan memiliki tujuan tertentu. Tujuan pemberian kredit tersebut tidak akan terlepas dari misi bank pemberian kredit (Purnawati, 2014).

Pada dasarnya fungsi kredit ialah pelayanan kepada masyarakat dalam memenuhi kebutuhannya untuk meningkatkan usahanya (Ismail, 2010). Masyarakat di sini merupakan individu, pengusaha, lembaga dan badan usaha yang membutuhkan dana. Kredit berfungsi membantu masyarakat dalam memenuhi kebutuhannya melalui penyaluran dana yang diberikan oleh bank.

Dana-dana yang disalurkan dalam bentuk kredit merupakan modal LPD dan dana yang disimpah oleh masyarakat (tabungan). Karena dana yang disalurkan tidak hanya berasal dari modal LPD, maka dalam penyaluran dana kepada masyarakat LPD penuh dengan risiko. Risiko-risiko yang terjadi karena penyaluran kredit sangat berbahaya dan akan berdampak pada keuangan LPD. Risiko dalam penyaluran kredit yang sering dihadapi oleh lembaga keuangan khususnya LPD adalah kredit bermasalah. Terjadinya kredit bermasalah merupakan hal umum dalam dunia perbankan.

Kredit bermasalah merupakan kredit yang telah disalurkan oleh bank, dan nasabah tidak dapat melakukan pembayaran atau melakukan angsuran sesuai dengan perjanjian yang telah ditandatangai oleh bank dan nasabah (Ismail, 2010). Selain itu, kredit bermasalah adalah suatu kondisi dimana debitur mengingkari janji mereka membayar bunga dan atau kredit induk yang telah jatuh tempo (Zulbiah dan Rodhiyah, 2017).

Kredit bermasalah mempunyai konsekwensi buruk terhadap likuiditas bank dan meningkatkan kerugian bagi bank, kerugian tentunya tidak diinginkan, karena kerugian dapat mengurangi cadangan atau modal, yang bisa menguras kekuatan keuangan bank. Walaupun berbagai usaha sudah dilakukan untuk pencegahannya, (seperti melalui penyempurnaan sistem serta kebijakan perkreditan ataupun dengan peningkatan mutu dan kualitas staf perkreditan) belum menutup kemungkinan terjadinya kredit bermasalah di masa mendatang.

Penggolongan kualitas kredit ada 5, yaitu lancar artinya kredit yang disalurkan tidak menimbulkan masalah, dalam perhatian khusus artinya kredit yang diberikan suatu mulai bermasalah sehingga perlu perhatian, kurang lancar artinya apabila kredit yang diberikan pembayarannya sudah mulai tersendatsendat, diragukan artinya kemampuan nasabah untuk membayar makin tidak dapat dipastikan, dan macet apabila nasabah sudak tidak mampu lagi untuk membayar pinjamannya, sehingga perlu diselamatkan. Yang tergolong kredit bermasalah adalah kurang lancar, diragukan, dan macet.

Kredit bermasalah akan berakibat pada kerugian bank, yaitu kerugian karena tidak diterimanya kembali dana yang telah disalurkan, maupun pendapatan bunga yang tidak dapat diterima. Artinya, bank kehilangan kesempatan mendapat bunga, yang berakibat pada penurunan pendapatan secara total. Untuk meminimalisir terjadinya kredit bermasalah maka perlu dilakukan analisis terhadap 
faktor-faktor yang mempengaruhi kredit bermasalah. Penyebab kredit bermasalah tidak hanya berasal dari debitur, namun juga berasal dari bank itu sendiri.

Terdapat dua faktor yang menyebabkan kredit bermasalah, yaitu faktor dari dalam bank itu sendiri (faktor internal) dan faktor dari luar bank (faktor eksternal). Faktor internal merupakan faktor yang berasal dari dalam bank yang meliputi berhubungan dengan kepentingan pribadi, kompromi terhadap prinsip-prinsip kredit, kebijakan perkreditan yang kurang sehat, tidak lengkapnya informasi kredit, kurang menguasai teknik perkreditan, pemberian kredit yang melampaui batas, dan ketatnya persainagan. Sedangkan faktor eksternal merupakan faktor yang berasal dari luar bank atau berasal dari debitur. Faktor eksternal meliputi faktor manajemen, dan faktor kondsi usaha (Iskandar, 2013).

Pengawasan kredit mempunyai fungsi untuk mengetahui secara dini penyimpangan yang terjadi atas penyaluran kredit kepada debitur (Fatimah, 2017). Pengawasan kredit membantu pihak bank untuk dapat segera mengambil langkahlangkah yang tepat serta dapat mendeteksi penyimpangan sedini mungkin untuk mengantisipasi kredit bermasalah.
Berdasarkan observasi yang dilakukan pada LPD Desa Pakraman Sidetapa, diketahui bahwa LPD tersebut memiliki permasalahan. Permasalahan yang dihadapi oleh LPD Desa Pakraman Sidetapa adalah minat masyarakat untuk menabung masih rendah dan kredit bermasalah. Menurut pegawai LPD bagian kredit, kredit bermasalah adalah permasalahan yang paling dirasakan dan sulit untuk diatasi. Selain itu, kredit bermasalah akan mengancam kondisi keuangan LPD Desa Pakraman Sidetapa jika tidak ditangani. Ketidakpastian penyebab kredit bermasalah pada LPD Desa Pakraman Sidetapa menyebabkan pihak LPD sulit untuk mengambil kebijakan dalam mengatasi terjadinya kredit bermasalah. Ada beberapa usaha yang dilakukan oleh LPD untuk dapat meminimalisir kredit bermasalah, salah satunya adalah meningkatkan pengawasan dan analisis kredit. Dilihat pada laporan tahunan LPD Desa Pakraman Sidetapa, kredit bermasalah yang terjadi tidak stabil. Adapun data kredit yang disalurkan LPD Desa Pakraman Sidetapa Periode 20152018 dapat dilihat pada tabel 1.

Tabel 1. Jumlah Kredit yang Disalurkan LPD Desa Pakraman Sidetapa Periode 2015/2018

\begin{tabular}{|c|c|c|c|c|c|}
\hline & & & & Persentase & \\
\hline Tahun & Jumlah & $\begin{array}{c}\text { Penyaluran } \\
\text { Kredit }\end{array}$ & $\begin{array}{l}\text { Jumlah Kredit } \\
\text { Bermasalah }\end{array}$ & $\begin{array}{c}\text { Jumlah } \\
\text { Kredit } \\
\text { Bermasalah }\end{array}$ & $\begin{array}{l}\text { Jumlah } \\
\text { Nasabah } \\
\text { Bermasalah }\end{array}$ \\
\hline 2015 & Rp 842.984.000 & - & Rp 141.342.000 & $16 \%$ & 21 \\
\hline 2016 & Rp 1.001.451.000 & Rp 158.467.000 & Rp 258.204.000 & $27 \%$ & 156 \\
\hline 2017 & Rp 1.106.454.000 & Rp 105.003.000 & Rp 142.924.000 & $13 \%$ & 83 \\
\hline 2018 & Rp 1.284.161.000 & Rp 177.707.000 & Rp 282.803.000 & $22 \%$ & 137 \\
\hline
\end{tabular}

Sumber Data: Laporan Tahunan LPD Desa Pakraman Sidetapa PeriodeTahun 2015-2018

Berdasarkan data pada tabel 1 dapat diketahui bahwa jumlah kredit yang disalurkan LPD Desa Pakraman Sidetapa dari tahun 2015 s/d tahun 2018 dilihat dari segi jumlah menunjukkan adanya peningkatan yang cukup tinggi. Dari tahun 2015 jumlah kredit yang disalurkan sebesar Rp 842.948.000 hingga tahun 2018 menjadi Rp 1.284.161.000. Dari laporan Tahunan LPD Desa Pakraman Sidetapa terlihat presentase jumlah kredit bermasalah pada tahun 2015 sebesar 16\% dengan jumlah nasabah yang bermasalah 21 orang, mengalami peningkatan pada tahun 2016 menjadi $27 \%$ dengan jumlah nasabah 156 orang, menurun menjadi $13 \%$ pada tahun 2017 dengan jumlah nasabah 83 orang dan mengalami peningkatan menjadi $23 \%$ pada tahun 2018 dengan jumlah nasabah 137 orang. Untuk mengatasi agar presentase 
jumlah kredit bermasalah, LPD Desa Pakraman Sidetapa menggunakan Cadangan Pinjaman Ragu-Ragu (CPRR), sehingga pada laporan tahunan presentase jumlah kredit bermaslah tidak terlalu tinggi.

Adapun tujuan dari penelitian ini adalah untuk mengetahui faktor-faktor yang mempengaruhi kredit bermasalah pada LPD Desa Pakraman Sidetapa, Kecamatan Banjar, Kabupaten Buleleng dan faktor yang dominan mempengaruhi kredit bermasalah pada LPD Desa Pakraman Sidetapa, Kecamatan Banjar, Kabupaten Buleleng.

\section{METODE}

Penelitian ini merupakan penelitian faktorial, dan data dalam penelitian ini akan dianalisis dengan analisis faktor. Penelitian ini dilakukan pada LPD Desa Pakraman Sidetapa, Kecamatan Banjar, Kabupaten Buleleng. Populasi pada penelitian ini adalah 137 (seratus tiga puluh tujuh) orang debitur pada LPD Desa Pakraman Sidetapa. Teknik pengambilan sampel dalam penelitian ini menggunakan teknik nonprobability sampling yaitu, sampling purposive. Sampling purposive adalah suatu teknik penentuan sampel dengan cara menentukan ciri-ciri khusus yang sesuai dengan tujuan penelitian sehingga diharapkan menjawab permasalahan penelitian .Pada penelitian ini sampel yang digunakan sebanyak 60 responden. Data penelitian ini dikumpulkan dengan menggunakan kuesioner yang kemudian diolah dengan analisis faktor dengan bantuan SPSS 16.0 for Windows.

\section{HASIL DAN PEMBAHASAN \\ Faktor-faktor yang Mempengaruhi Kredit Bermasalah pada LPD Desa Pakraman Sidetapa}

Untuk mengetahui faktor-faktor yang mempengaruhi kredit bermasalah digunakan analisis faktor. Analisis faktor digunakan untuk menguji hipotesis dengan memasukkan semua total nilai dari masingmasing dimensi atau faktor terhadap total skor item dari masing-masing dimensi. Skor dari masing-masing dimensi terlebih dahulu ditransformasikan ke dalam data interval kemudian dilakukan penentuan matrik korelasi, penentuan jumlah faktor, membuat rotasi faktor dan menentukan skor masingmasing faktor. Untuk dapat mengukur kecukupan sampel dalam penelitian ini digunakan Koefisien Kaiser-Mayer-Olkin (KMO), dengan nilai KMO minimal 0,50. Hasil dari pengukuran kecukupan sampel menggunakan KMO pada penelitian ini dapat dilihat pada tabel 2 .

Tabel 2. Hasil untuk Penelitian KMO and Barlett's Test of Sphericity

\begin{tabular}{lrr}
\hline \multicolumn{2}{c}{ KMO and Bartlett's Test } \\
\hline Kaiser-Meyer-Olkin Measure of Sampling Adequacy. & .726 \\
Bartlett's Test of Sphericity & Approx. Chi-Square & 173.322 \\
& Df & 28 \\
& Sig. & .000 \\
\hline
\end{tabular}

Sumber: Data Diolah, 2019

Berdasarkan data pada tabel 2 dapat dilihat bahwa hasil analisis faktor menunjukkan bahwa nilai $\mathrm{KMO}$ sebesar 0,726 lebih besar dari 0,50. Hal ini menunjukkan bahwa jumlah sampel yang digunakan sudah cukup memenuhi syarat dan analisis faktor tetap digunakan untuk menganalisis data dalam penelitian ini. Pengujian Barlett's Test of Sphericity menunjukkan hasil penelitian yang signifikan dengan taraf nyata $0.000<0,05$, artinya matrik kolerasi memiliki kolerasi yang signifikan dengan sejumlah variabel.

Untuk mengetahui faktor-faktor atau variabel yang layak digunakan dalam analisis faktor dapat dilihat pada output SPSS 16.0 for Windows. Pada output SPSS (Anti-image Matrices), terdapat kode "a" yang artinya tanda untuk nilai Measure of Sampling Adequacy (MSA). Faktor yang layak digunakan adalah faktor yang memiliki MSA > 0,50, dan apabila terdapat 
faktor yang memiliki nilai MSA $<0,50$, maka faktor tersebut dikeluarkan. Nilai MSA pada masing-masing faktor pada penelitian ini dapat dilihat pada tabel 3 .

Tabel 3. Nilai MSA Masing-Masing Faktor

\begin{tabular}{|c|c|c|}
\hline Faktor & Nilai MSA & Keputusan \\
\hline Berhubungan dengan Kepentingan & $0,896>0,05$ & Dapat digunakan untuk analisis faktor \\
\hline $\begin{array}{l}\text { Pribadi } \\
\text { Princin }\end{array}$ & & \\
\hline $\begin{array}{l}\text { Kompromi Terhadap } \\
\text { Prinsip Kredit }\end{array}$ & $0,659>0,50$ & Dapat digunakan untuk analisis faktor \\
\hline $\begin{array}{l}\text { Kebijakan Perkreditan yang Kurang } \\
\text { Sehat }\end{array}$ & $0,651>0,50$ & Dapat digunakan untuk analisis faktor \\
\hline Tidak Lengkapnya Informasi Kredit & $0,701>0,50$ & Dapat digunakan untuk analisis faktor \\
\hline $\begin{array}{l}\text { Kurangnya Petugas Menguasai } \\
\text { Teknik Perkreditan }\end{array}$ & $0,837>0,50$ & Dapat digunakan untuk analisis faktor \\
\hline $\begin{array}{l}\text { Pemberian Kredit yang Melampaui } \\
\text { Batas }\end{array}$ & $0,880>0,50$ & Dapat digunakan untuk analisis faktor \\
\hline Pengelolaan Kredit & $0,704>0,50$ & Dapat digunakan untuk analisis faktor \\
\hline Kondisi Usaha & $0,554>0,50$ & Dapat digunakan untuk analisis faktor \\
\hline
\end{tabular}

Sumber: Data Diolah, 2019

Berdasarkan data pada tabel 3 dapat dilihat bahwa setelah diuji Measure of Sampling Adequacy (MSA) faktor berhubungan dengan kepentingan pribadi memiliki nilai MSA 0,896>0,05, faktor kompromi terhadap prinsip-prinsip kredit memiliki nilai MSA 0,659>0,50, faktor kebijakan perkreditan yang kurang sehat memiliki nilai MSA 0,651 >0,50, faktor tidak lengkapnya informasi kredit memiliki nilai MSA 0,701 > 0,50, faktor kurangnya petugas menguasai teknik perkreditan memiliki nilai MSA 0,837>0,50, faktor pemberian kredit yang melampau batas memiliki nilai MSA $0,880>0,50$, faktor pengelolaan kredit memiliki nilai MSA 0,704
$>0,50$, dan faktor kondisi usaha memiliki nilai MSA $0,554>0,50$. Banyaknya faktor yang mempengaruhi kredit bermasalah pada LPD Desa Pakraman Sidetapa dapat dijelaskan dengan nilai Total Variance Explained, yang digunakan untuk mengetahui persentase dari 8 (delapan) faktor, yaitu berhubungan dengan kepentingan pribadi, kompromi terhadap prinsip-prinsip kredit, kebijakan perkreditan yang salah, tidak lengkapnya informasi kredit, penguasaan teknik perkreditan, pemberian kredit yang melampau batas, pengelolaan kredit, dan kondisi usaha. Hasil Total Variance Explained dapat dilihat pada tabel

Tabel 4. Hasil Analisis Total Variance Explained

\begin{tabular}{|c|c|c|c|c|c|c|}
\hline \multirow{2}{*}{ Component } & \multicolumn{3}{|c|}{ Initial Eigenvalues } & \multicolumn{3}{|c|}{ Extraction Sums of Squared Loadings } \\
\hline & Total & $\%$ of Variance & Cumulative \% & Total & $\%$ of Variance & Cumulative $\%$ \\
\hline $\mathrm{X} 1.1$ & 0.397 & 4.965 & 4.965 & & & \\
\hline$X 1.2$ & 3.776 & 47.199 & 52.162 & 3.776 & 47.199 & 47.199 \\
\hline $\mathrm{X} 1.3$ & 0.170 & 2.126 & 54.288 & & & \\
\hline $\mathrm{X} 1.4$ & 0.709 & 8.863 & 63.151 & & & \\
\hline $\mathrm{X} 1.5$ & 0.764 & 9.546 & 72.697 & & & \\
\hline $\mathrm{X} 1.6$ & 0.640 & 8.003 & 80.700 & & & \\
\hline $\mathrm{X} 1.7$ & 0.459 & 5.737 & 86.437 & & & \\
\hline $\mathrm{X} 1.8$ & 1.085 & 13.563 & 100.000 & 1.085 & 13.563 & 60.761 \\
\hline
\end{tabular}

Extraction Method: Principal Component Analysis.

Sumber: Data Diolah, 2019 
Berdasarkan data pada tabel 4 dapat ditunjukkan bahwa faktor faktor berhubungan dengan kepentingan pribadi memiliki eigenvalue sebesar 0.397 dengan nilai varian sebesar $4.965 \%$, (2) faktor kompromi terhadap prinsip-prinsip kredit memiliki eigenvalue sebesar 3.776 dengan nilai varian sebesar $47.199 \%$, (3) faktor kebijakan perkreditan yang kurang sehat memiliki eigenvalue sebesar 0.170 dengan nilai varian sebesar $2.126 \%$, (4) faktor tidak lengkapnya informasi kredit memiliki eigenvalue sebesar 0.709 dengan nilai varian sebesar $8.863 \%$, (5) faktor kurangnya petugas menguasai teknik perkreditan memiliki eigenvalue sebesar 0.764 dengan nilai varian sebesar $9.546 \%$, (6) faktor pemberian kredit yang melampaui batas memiliki eigenvalue sebesar 0.640 dengan nilai varian sebesar $8.003 \%$, (7) faktor pengelolaan kredit memiliki eigenvalue sebesar 0.459 dengan nilai varian sebesar $5737 \%$, dan (8) faktor kondisi usaha memiliki eigenvalue sebesar 1.085 dengan nilai varian sebesar $13.563 \%$. Dari 8 faktor, yaitu berhubungan dengan kepentingan pribadi, kompromi terhadap prinsip-prinsip kredit, kebijakan perkreditan yang salah, tidak lengkapnya informasi kredit, penguasaan teknik perkreditan, pemberian kredit yang melampau batas, pengelolaan kredit, dan kondisi usaha, maka faktor yang dapat menjelaskan kredit bermasalah pada LPD Desa Pakraman Sidetapa dapat ditunjukkan dengan ekstraksi faktor.

Ekstraksi faktor dapat dijelaskan oleh total persentase masing-masing faktor utama. Faktor utama tersebut adalah kebijakan perkreditan yang kurang sehat dan pengelolaan kredit yang memiliki eigenvalue $>1$. Untuk mengetahui distribusi dimensi-dimensi yang belum dirotasi ke dalam faktor yang telah terbentuk, maka dapat dilihat Rotated Component Matrix seperti pada tabel 5.

Tabel 5. Faktor yang Menjelaskan Kredit Bermasalah pada LPD Desa Pakraman Sidetapa

\begin{tabular}{cc}
\hline Faktor & Eigenvalues \\
\hline X1.1 & 0.397 \\
X1.2 & 3.776 \\
X1.3 & 0.170 \\
X1.4 & 0.709 \\
X1.5 & 0.764 \\
X1.6 & 0.640 \\
X1.7 & 0.459 \\
X1.8 & 1.085 \\
\hline
\end{tabular}

Variance Explained (\%)
4.965
47.199
2.126
8.863
9.546
8.003
5.737
13.563

Loading Factor

0.567

0.800

0.548

0.012

0.771

0.698

13.563

0.993

0.894

Sumber: Data Diolah, 2019

Berdasarkan data pada tabel 5 dapat ditunjukkan bahwa nilai eigenvalues faktor yang memiliki nilai eigenvalue $>1$ adalah faktor kebijakan perkreditan yang kurang sehat dan pengelolaan kredit. Nilai varianced explained faktor kompromi terhadap prinsip-prinsip kredit sebesar $47.199 \%$ serta kondisi usaha sebesar $13.563 \%$. Total nilai varianced explained dari kedua faktor keseluruhan mampu menjelaskan sebesar $60.762 \%$. Dengan demikian, $60.762 \%$ dari seluruh variabel yang ada dapat dijelaskan oleh 2 faktor yang terbentuk. Faktor kompromi terhadap prinsip-prinsip perkreditan memiliki varianced explained $47.199 \%$, artinya faktor kompromi terhadap prinsip-prinsip perkreditan mempengaruhi kredit bermasalah pada LPD Desa Pakraman Sidetapa sebesar $47.199 \%$. Faktor kondisi usaha memiliki varianced explained $13.563 \%$, artinya faktor kondisi usaha mempengaruhi kredit bermasalah pada LPD Desa Pakraman Sidetapa sebesar $13.563 \%$.

Penentuan nama faktor yang telah terbentuk untuk masing-masing faktor bersifat subjektif, sebagian besar variabel yang memiliki nilai loading factor tertinggi digunakan untuk memberi nama faktor. Untuk melihat nilai loading factor dapat dilihat pada tabel 6 . 
Tabel 6. Rotated Component Matrix

\begin{tabular}{ccc}
\hline Faktor & \multicolumn{2}{c}{ Component } \\
\cline { 2 - 3 } & 1 & 2 \\
\hline X1.1 & 0.800 & 0.277 \\
X1.3 & 0.771 & 0.205 \\
X1.4 & 0.717 & 0.012 \\
X1.5 & 0.567 & 0.439 \\
X1.6 & 0.548 & 0.514 \\
X1.7 & 0.056 & 0.849 \\
X1.8 & 0.325 & 0.698 \\
\hline
\end{tabular}

Sumber: Data Diolah, 2019

Berdasarkan data pada tabel 6 dapat ditunjukkan bahwa faktor yang mempengaruhi kredit bermasalah pada LPD Desa Pakraman Sidetapa dapat dikelompokan menjadi 2 faktor. Faktor 1 (satu) terbentuk dari faktor berhubungan dengan kepentingan pribadi (X1.1) dengan loading factor sebesar 0.567, faktor kompromi terhadap prinsip-prinsip kredit (X1.2) dengan loading factor sebesar 0.800 , faktor kebijakan perkreditan yang kurang sehat (X13) dengan loading factor sebesar 0.548, faktor tidak lengkapnya informasi kredit (X1.4) dengan loading factor sebesar 0.717 , faktor kurangnya petugas menguasai teknik perkreditan (X1.5) dengan loading factor sebesar 0.771. Faktor 2 (dua)

terbentuk dari faktor pemberian kredit yang melampaui batas (X1.6) dengan loading factor sebesar 0.698, faktor pengelolaan kredit (X1.7) dengan loading factor sebesar 0.693, faktor kondisi usaha (X1.8) dengan loading factor sebesar 0.849 .

\section{Faktor yang Paling Dominan Mempengaruhi Kredit Bermasalah pada LPD Desa Pakraman Sidetapa}

Penentuan faktor yang paling dominan mempengaruhi kredit bermasalah pada LPD Desa Pakraman Sidetapa menggunakan parameter koefisien varimax. Hasil ringkasan rotasi dari matriks faktor memuat nilai varimax rotation dapat dilihat pada tabel

Tabel 7. Matriks Rotasi Hasil Anallisis Faktor

\begin{tabular}{lcc}
\hline Faktor yang Mempengaruhi Kredit Bermasalah & \multicolumn{2}{c}{ Varimax Rotation (\%) } \\
\cline { 2 - 3 } Kebijakan perkreditan yang kurang sehat & 47.199 & - \\
Pengelolaan kredit & - & 13.563 \\
\hline
\end{tabular}

Sumber: Data Diolah, 2019

Berdasarkan data pada tabel 7 dapat ditunjukkan bahwa faktor yang paling dominan mempengaruhi kredit bermasalah pada LPD Desa Pakraman Sidetapa adalah kompromi terhadap prinsip-prinsip kredit dengan varimax rotation sebesar $47.199 \%$, artinya kejelasan dari faktor yang mempengaruhi kredit bermasalah adalah kompromi terhadap prinsip-prinsip kredit yang paling mendominasi sebesar 47.199\%. Kompromi terhadap prinsipprinsip kredit artinya pihak LPD memberikan kelonggaran bagi debitur dalam proses analisis kredit yaitu, analisis 5C yang terdiri dari character, capacity, capital, collateral, dan condition of economy. Sebagai contoh pihak LPD kemungkinan mengabaikan collateral, yaitu jaminan/agunan yang diberikan oleh calon debitur atas kredit yang diajukan. Meskipun jaminan yang diberikan debitur tidak sesuai dengan nilai kredit yang diajukan, pihak LPD tetap menyetujui pengajuan kredit dari debitur. 


\section{Pembahasan}

Faktor-faktor yang mempengaruhi
kredit bermasalah pada LPD Desa Pakraman Sidetapa adalah berhubungan dengan kepentingan pribadi, kompromi terhadap prinsip-prinsip kredit, kebijakan kredit yang kurang sehat, tidak lengkapnya informasi kredit, kurangnya petugas memahami teknik perkreditan, pemberian kredit yang melampaui batas, pengelolaan kredit, kondisi usaha. Hal ini sesuai dengan teori yang dikemukakan oleh (Iskandar, 2013) bahwa kredit bermasalah dapat disebabkan oleh dua faktor yaitu faktor internal dan faktor eksternal. Faktor internal terdiri dari berhubungan dengan kepentingan pribadi, kompromi terhadap prinsip-prinsip kredit, kebijakan kredit yang kurang sehat, tidak lengkapnya informasi kredit, kurangnya petugas memahami teknik perkreditan, dan pemberian kredit yang melampaui batas. Sedangkan faktor eksternal terdiri dari pengelolaan kredit, dan kondisi usaha. Dengan demikian, untuk menjelaskan faktor yang mempengaruhi kredit bermasalah pada LPD Desa Pakraman Sidetapa, dapat dilihat dari faktor-faktor yang memiliki eigenvalue > 1 yaitu, faktor kompromi terhadap prinsipprinsip kredit dan kondisi usaha.

Faktor kompromi terhadap prinsipprinsip perkreditan dan kondisi usaha merupakan faktor yang paling dominan mempengaruhi kredit bermasalah pada LPD Desa Pakraman Sidetapa. Faktor kompromi terhadap prinsip-prinsip kredit paling dominan dibandingkan dengan faktor yang lain disebabkan karena kompromi terhadap prinsip perkreditan berakibat yang fatal terhadap. Kompromi terhadap prinsipprinsip perkreditan artinya memberikan keringanan kepada debitur dalam hal analisis kredit. Analisis kredit merupakan hal yang penting dalam proses pemberian kredit, hal ini akan memberikan peluang terjadinya kredit bermasalah karena analisis kredit tidak dijalankan dengan benar. Hasil penelitian ini mendukung teorinya (Iskandar, 2013), yang menyatakan bahwa Pemimpin bank dengan berbagai alasan adakalanya dapat menyetujui pemberian kredit yang mengandung risiko yang tidak layak atau dengan syarat yang tidak dapat dibenarkan yang diketahui melanggar prinsip-prinsip kredit. Alasan untuk berkompromi yang bertentangan dengan prinsip kredit, dapat disebabkan keeratan hubungan dengan mereka yang berkuasa atau pihak-pihak yang dapat sangat berpengaruh. Hasil penelitian ini sejalan dengan hasil penelitian yang dilakukan oleh (Arwana, 2015), yang menyatakan bahwa faktor yang paling dominan mempengaruhi kredit bermasalah adalah analisis kredit.

Kondisi usaha merupakan keadaann usaha yang sedang dijalankan oleh debitur. Kondisi usaha akan berpengaruh pada kemampuan debitur dalam pembayaran kredit. Jika kondisi usaha debitur baik maka pembayaran kredit debitur akan lancar, dan apabila kondisi usaha debitur buruk maka pembayaran kredit debitur tidak lancar. Hal ini sesuai dengan teori (Iskandar, 2013) yang menyatakan bahwa salah satu faktor yang mempengaruhi kredit bermasalah adalah kondisi usaha. Hasil penelitian ini sejalan dengan hasil penelitian yang dilakukan oleh (Thamrin, 2016) yang menyatakan bahwa faktor yang mempengaruhi kredit bermasalah adalah faktor kondisi usaha.

\section{SIMPULAN DAN SARAN Simpulan}

Faktor-faktor yang mempengaruhi kredit bermasalah pada Lembaga Perkreditan Desa (LPD) Desa Pakraman Sidetapa, Kecamatan Banjar, Kabupaten Buleleng adalah faktor berhubungan dengan kepentingan pribadi dengan nilai variance sebesar $4,965 \%$, faktor kompromi terhadap prinsip-prinsip perkreditan dengan nilai variance sebesar 47,199\%, faktor kebijakan perkreditan yang kurang sehat dengan nilai variance sebesar $2.126 \%$, faktor tidak lengkapnya informasi kredit dengan nilai variance sebesar 8,863\%, faktor kurangnya petugas menguasai teknik perkreditan dengan nilai variance sebesar $9,546 \%$, faktor pemberian kredit yang melampaui batas dengan nilai variance sebesar $8,003 \%$, faktor pengelolaan kredit dengan nilai variance sebesar $5,737 \%$, dan kondisi usaha dengan nilai variance sebesar $13,563 \%$.

Faktor yang paling dominan mempengaruhi kredit bermasalah pada 
LPD Desa Pakraman Sidetapa, Kecamatan Banjar, Kabupaten Buleleng adalah faktor kompromi terhadap prinsip-prinsip kredit dengan varimax ratation sebesar 47,199\%.

\section{Saran}

Bagi LPD Desa Pakraman Sidetapa dalam pemberian kredit agar berpegang teguh pada prinsip 5C, tidak memberikan kompromi kepada debitur dan meningkatkan pengawasan terhadap penggunaan dana kredit maupun usaha debitur. Selain itu, agar meningkatkan prinsip kehati-hatian, tidak mudah percaya kepada nasabah dan dalam memutuskan pemberian kredit lebih mempertimbangkan jaminan serta melihat keadaan ekonomi dari calon debitur. Jika LPD mampu menerapkan hal-hal tersebut, maka LPD dapat meminimalisir terjadinya kredit bermasalah .

Bagi peneliti selanjutnya diharapkan untuk mengembangkan penelitian ini dengan meneliti faktor-faktor lain yang memungkinkan mempengaruhi kredit bermasalah. Sehingga kredit bermasalah tidak hanya dipengaruhi oleh faktor berhubungan dengan kepentingan pribadi, faktor kompromi terhadap prinsip-prinsip kredit, faktor kebijakan perkreditan yang kurang sehat, faktor tidak lengkapnya informasi kredit, faktor kurangnya petugas menguasai teknik perkreditan, faktor pemberian kredit yang melampaui batas, faktor pengelolaan kredit dan faktor kondisi usaha saja tetapi ada faktor lain yang mempengaruhi kredit bermasalah.

\section{DAFTAR PUSTAKA}

Abdulah, and Tantri. 2012. Bank Dan Lembaga Keuangan. Jakarta: PT Raja Grafindo Persada.

Arwana, Revi. 2015. Analisis Faktor-Faktor Penyebab Terjadinya Kredit Macet Pada Lembaga Perkreditan Desa (LPD) Di Kabupaten Buleleng. Jurnal IImiah Mahasiswa Akuntansi Undiksha 3: 15-20.

Fatimah. 2017. "Pengaruh Analisis Kredit Dan Pengawasan Kredit Terhadap Kredit Bermasalah Pada PT Bank Perkreditan Rakyat Dana Nagoya Di Kota Batam." Jurnal Akuntansi
Barelang 2: 50-56.

Herli, Ali Suyanto. 2013. Buku Pintar Pengelolaan BPR Dan Lembaga Keuangan Pembiayaan Mikro. Yogyakarta: Andi.

Iskandar, Syamsu. 2013. Bank Dan Lembaga Keuangan Lainnya. Jakarta: In Media.

Ismail. 2010. Manajemen Perbankan Dari Teori Menuju Aplikasi. Jakarta: Kencana.

Lapoliwa, dan Kuswandi. 2000. Akuntansi Perbankan: Akuntansi Transaksi Bank Dalam Valuta Rupiah. Jakarta: Instud Bankir Indonesia.

Purnawati, I Gusti Ayu, Dkk. 2014. Akuntasi Pebankan Teori Dan Soal Latihan. Jakarta: Graha IImu.

Sudirman, Wayan. 2000. Manajemen Perbankan Suatu Aplikasi Dasar. Denpasar: PT BP Denpasar.

Supriyono. 2011. Buku Pintar Perbankan. Yogyakarta: Andi.

Thamrin, Answar T. 2016. "Analisis FaktorFaktor Yang Mempengaruhi Kredit Bermasalah Pada PT Bank Rakyat Indonesia (Persero) Tbk Unit Solo Kabupaten Pinrang." Fakultas Ekonomi Negeri Malang 2: 40-45.

Wahjono, Sentor Imam. 2010. Manajemen Pemasaran. Yogyakarta: Graha Ilmu.

Zulbiah, and Rodhiyah. 2017. "Analisis Faktor-Faktor Yang Mempengaruhi Kredit Bermasalah Pada Nasabah Kredit PD. BPR Bank Daerah Kabupaten Madiun Cabang Bojonegoro." Jurnal IImu Administrasi Bisnis 6: 11-21. 